\title{
PENGARUH METODE PEMBELAJARAN BRAINSTORMING TERHADAP KEMAMPUAN BERPIKIRKRITIS MATERI VERTEBRATA PADA SISWA SMA
}

\author{
Dzaalika Aldeirre $^{1)}$, Ratna Komala ${ }^{2)}$, Erna Heryanti ${ }^{3)}$ \\ ${ }^{1)}$ Pendidikan Biologi, FPMIPA, Universitas Negeri Jakarta \\ email: dzaaldeirre@gmail.com \\ Diterima 1 Oktober 2018 disetujui 10 Oktober 2018
}

\begin{abstract}
Brainstorming Learning Method is one of the learning methods that help teachers to achieve the goals of the learning process. Critical thinking is a process for learners to digest first things that have been obtained by looking at from other sources then can create their own conclusions. One of learning that requires critical thinking is Vertebrate subject matter. This study aims to determine the effect of brainstorming learning method on critical thinking of Vertebrate subject matter in high school students. This research was conducted in SMA Negeri 31 Jakarta. The number of research samples were 132 students using Taro Yamane formula selected by simple random sampling. This research was conducted in May-June 2018. The research method used is quasi-experimental method. The result of the research is the average score of critical thinking ability test of Vertebrata subject matter in experiment classis higher than the average score of critical thinking ability test of Vertebrate material in control class, prerequisite test shows normal and homogenous distribution data. Testing statistical hypothesis based on calculations that have been done, obtained $p$-value $<\alpha$ is $0,000<0.05$ then. The conclusion of this research is the influence of brainstorming method on Vertebrate subject matter critical thinking ability in high school students.
\end{abstract}

Kata kunci: Metode Brainstorming; Berpikir Kritis; Materi Vertebrata

\section{PENDAHULUAN}


Pembelajaran merupakan proses interaksi peserta didik dengan guru dan sumber belajar pada suatu lingkungan belajar. Proses pembelajaran perlu direncanakan, dilaksanakan, dinilai dan diawasiagar terlaksana secara efektif dan efesien (Rusman, 2010). Pembelajaran dapat dilakukan dengan menggunakan metode ilmiah yang diintegrasikan dengan pendekatan, strategi, model dan metode pembelajaran. Salah satu jenis metode pembelajaran adalah metode pembelajaran brainstorming. Metode pembelajaran brainstorming adalah metode pembelajaran yang memberikan kesempatan bagi peserta didik untuk menyatakan pendapat ataupun gagasan mereka mengenai materi pembelajaran, akan tetapi gagasan yang diberikan tidakakan dikritik oleh peserta didik yang lainnya (Sijabat,2013). Metode pembelajaran brainstorming diharapkan dapat meningkatkan kemampuan berpikir kritis oleh peserta didik karena peserta didik diberikan kesempatan untuk menyampaikan pendapat mereka tanpa adanya rasa taku takan kritikan.

Berfikir kritis merupakan proses dimana peserta didik mengolah terlebih dahulu mengenai hal yang mereka dapatkan dengan cara mengumpulkan berbagai bukti lain yang terkait dari sumber yang berbeda. Kemampuan berpikir kritis masyarakat Indonesia masih lemah. Kemampuan berpikir kritisitu kurang terbangun di pendidikan dan budaya Indonesia karena pendidikan Indonesia masih mengutamakan kemampuan menghafal (Wahyudi,2017). Berdasarkan penelitian yang dilakukan oleh Utami(2015) metode pembelajaran Brainstorming dapat meningkatkan kemampuan berpikir kritis peserta didik pada pembelajaran IPA. Keunggulan metode pembelajaran brainstorming yaitu: 1) anak-anak berpikir untuk menyatakan pendapat, 2) melatih peserta didik berpikir dengan cepat dan tersusun logis, 3) merangsang peserta didik untuk selalu siap berpendapat yang berhubungan dengan masalah yang diberikan oleh guru, 4) meningkatkan partisipasi peserta didik dalam menerima pembelajaran, 5) peserta didik yang kurang aktif mendapat bantuan dari temannya yang sudah pandai atau dari guru,6)terjadi persaingan yang sehat, 7) anak merasa bebas dan gembira dan 8) suasana demokratis dan disiplin dapat ditumbuhkan (Mukrima, 2014). Metode pembelajaran brainstorming juga diharapkan dapat meningkatkan berpikir kritis peserta didik karena setiap peserta didik akan memberikan pendapat mereka tanpa adanya rasa takut akan kritikan dari peserta didik lain.

Salah satu materi pembelajaran yang dianggap sulit oleh peserta didik adalah materi klasifikasi makhluk hidup. Materi tersebut memiliki tingkat kerumitan yang tinggi karena peserta didik dituntut untuk mendeskripsikan makhluk hidup berdasarkan ciri-ciri khusus yang dimiliki, sehingga materi ini memerlukan kemampuan berpikir kritis peserta didik dalam memecahkan permasalahan pada materi tersebut (Prihatiningsih, 2016). Salah satu materi yang menyangkut klasifikasi makhluk hidup adalah materi Vertebrata. Vertebrata merupakan hewan bertulang belakang yang klasifikasikan menjadi 7 kelompok diantaranya Agnatha, Chondrchthyes, Ostheichthyes, Amphibi, Reptilia, Aves dan Mamalia (Susatyo \& Sugiharto, 2016). Berdasarkan permasalahan diatas, maka penelitian ini dilakukan untuk melihat serta menganalis keefektifan dari metode pembelajaran brainstorming yang digunakan untuk dapat mempengaruhi cara berpikir kritis materi Vertebrata pada peserta didik SMA. Penelitian ini diharapkan dapat menjadi bahan acuan ke depan dalam mengimplementasikan metode pembelajaran yang dapat menjadikan peserta didik dapat berpikir kritis.

\section{METODOLOGI PENELITIAN}

Penelitian ini dilaksanakan di SMA Negeri 31 Jakarta Semester Genap Tahun Ajaran 2017/2018 pada bulan April 2018. 
Metode yang digunakan dalam penelitian ini adalah metode kuasi eksperimen dengan desain penelitian yang digunakan adalah posttest only group design.

\subsection{MetodePengumpulanData}

Populasi pada penelitian ini ialah siswa kelas X SMA Negeri 31 Jakarta. Sampel berjumlah 132 yang diambil menggunakan teknik simple random sampling. Data kemampuan berpikir kritis siswa diukur menggunakan instrument tes kemampuan berpikir kritis siswa yang terdiri atas 24 butir soal uraian dengan maksimal skor tiap soal adalah 4 .

\subsection{Metode Analisis \\ Data}

Pengolahan data dilakukan dengan perhitungan statistik, yaitu:

1. Uji Prasyarat Analisis

Data

a. Uji normalitas dilakukan untuk mengetahui data yang diperoleh berdistribusi normal atau tidak. Uji normalitas dilakukan dengan menggunakan uji KolmogorovSmirnov pada taraf signifikansi 0,05 dengan aplikasi SPSS vol.24.

b. Uji homogenitas dilakukan untuk mengetahui data memilliki varians yang sama atau tidak. Uji homogenitas dilakukan dengan menggunakan uji Levene pada taraf signifikansi 0,05 dengan aplikasi SPSS vol.24.

2. Uji Hipotesis

Jika data yang diperoleh merupakan data yang berdistribusi normal dan homogeny maka dilakukan uji hipotesis menggunakan uji-t pada taraf signifikansi 0,05 dengan aplikasi SPSS vol.24

\section{HASILDAN PEMBAHASAN}

Hasil yang didapatkan
menunjukkan skor maksimal yang

diperoleh kelas eksperimen adalah 97,91 dan skor terendah adalah 37,5. Histogram distribusi skor tes kemampuan berpikir kritis pada kelas eksperimen terlihat pada Gambar 1, sedangkan Histogram distribusi skor tes kemampuan berpikir kritis pada kelas eksperimen terlihat pada Gambar 2.

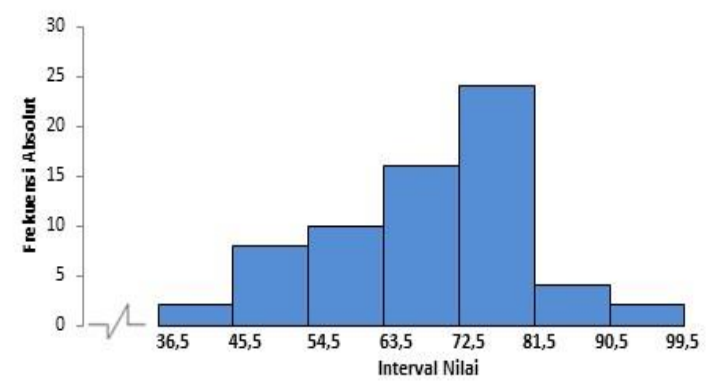

Gambar 1. Distribusi Skor Tes Kemampuan Berpikir Kritis pada Kelas Eksperimen

Skor tertinggi yang diperoleh siswa pada kelas eksperimen adalah 97,91 dan skor terendah adalah 37,5 dengan rata-rata skor tes kemampuan berpikir kritis yang diperoleh siswa adalah 68,78 sedangkan skor tertinggi yang diperoleh pada siswa pada kelas control adalah 83,33 dan skor terendah adalah 27,08 dengan rata-rata skor tes kemampuan berpikir ktritis yang diperoleh siswa adalah 58,90. Hal tersebut menunjukkan bahwa kelas eksperimen memperoleh skor tertinggi yang lebih besar dari kelas control serta memperoleh skor terendah dan rata-rata skor tes kemampuan berpikir kritis yang lebih besar dari kelas kontrol.

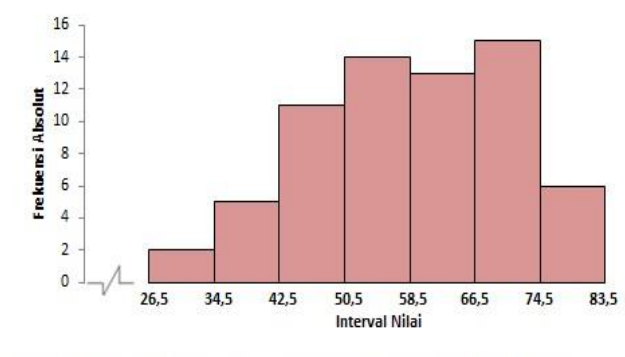

Gambar 2. Distribusi Skor Tes Kemampuan Berpikir Kritis pada Kelas Kontrol

Perbandingan rata-rata skor tes kemampuan berpikir kritis pada kelas eksperimen dan kelas control (Gambar 3) menunjukkan bahwa kelas eksperimen yang menggunakan metode brainstorming mendapatkan skor tes kemampuan berpikir 
kritis lebih besar daripada kelas kontrol. Dengan skor rata-rata pada kelas eksperimen adalah 68,78 dan skor rata-rata pada kelas kontrol adalah 58,9. Hal tersebut menunjukkan bahwa kelas eksperimen memperoleh skor tertinggi yang lebih besar dari kelas kontrol serta memperoleh skor terendah dan rata-rata skor tes kemampuan berpikir kritis yang lebih besar dari kelas kontrol.

Berdasarkan hasil yang diperoleh diketahui bahwa metode pembelajaran brainstorming mempengaruhi tingkat berpikir kritis siswa, dimana metode brainstorming memberikan kesempatan kepada peserta didik untuk menyampaikan pendapat mereka tanpa adanya rasa takut akan kritikan. Pendapat yang disampaikan oleh peserta didik membimbing peserta didik tersebut untuk berpikir lebih dalam sehingga mereka dapat menyampaikan pendapat mereka.

Pada perhitungan persentase pencapaian kategori kemampuan berpikir kritis, terlihat bahwa siswa yang mampu mencapai kategori kemampuan berpikir kritis sangat tinggi pada kelas eksperimen terdapat 2 siswa $(3,03 \%)$ dan tidak ada siswa pada kelas control yang mampu mencapai kategori kemampuan berpikir kritis sangat tinggi. Siswa yang termasuk ke dalam kategori kemampuan berpikir kritis sangat rendah pada kelas eksperimen terdapat 10 siswa $(15,15 \%)$ sedangkan pada kelas control mencapai 26 siswa $(39,39 \%)$.

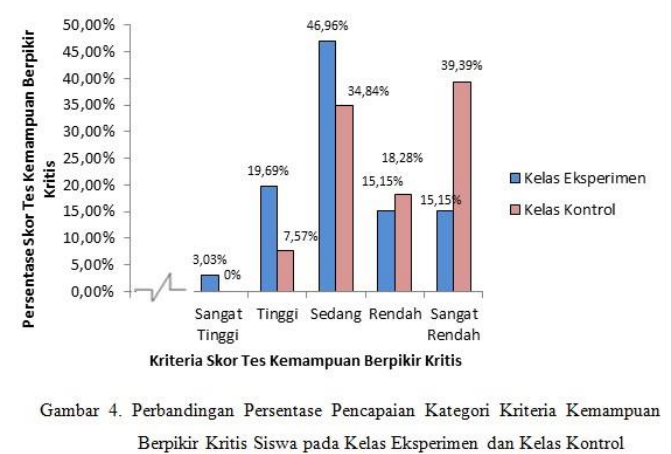

Hasil yang diperoleh sesuai dengan penelitian yang dilakukan oleh Utami (2015), bahwa metode brainstorming dapat mempengaruhi kemampuan berpikir kritis siswa. Metode pembelajaran brainstorming memungkinkan adanya permasalahan baru yang muncul selama proses pembelajaran berlangsung. Permasalahan yang baru muncul tersebut dikarenakan adanya kesempatan bagi para siswa untuk menyampaikan pendapatnya tanpa adanya kritikan dari siswa lain yang mendengarkan (Utami, 2015).

Tanpa adanya kritikan yang diajukan oleh siswa lainnya, setiap siswa menjadi lebih percaya diri dalam menyampaikan pendapat mereka tanpa rasa takut disalahkan oleh teman mereka. Hal tersebut memicu setiap siswa untuk dapat berpikir lebih dalam atau berpikir kritis untuk dapat menyampaikan pendapat mereka masing-masing. Tujuan dari penggunaan metode ini sendiri ialah untuk mengungkapkan semua yang dipikirkan oleh para siswa dalam menanggapi masalah yang dilontarkan guru selama proses pembelajaran.

Pada tahap stimulation, guru memulai pembelajaran dengan mengajukan pertanyaan, dan siswa diminta untuk mencari referensi dari berbagai sumber serta siswa belajar secara berkelompok yang terdiri dari 5-6 orang yang heterogen. Tahap stimulation membuat siswa terlebih dahulu memiliki pengetahuan sebelum memulai pembekalan materi Vertebrata. Pada tahap problem statement siswa melakukan identifikasi berbagai masalah mengenai Vertebrata dan merumuskannya dalam bentuk hipotesis. Selanjutnya tahap data collecting dan data processing, pada tahap inilah kemampuan berpikir kritis siswa dilatih sebab siswa diharuskan untuk menyampaikan pendapat mereka masingmasing mengenai permasalahan yang ada selain dari yang telah disampaikan teman mereka sebelumnya. 
Pada pertemuan pertama baik pada kelas Eksperimen maupun kelas kontrol, peserta didik melakukan pembahasan mengenai hewan Vertebrata pada kelas Agnatha, Chondochtyes, Osteicthyes serta Amphibi. Peserta didik dibagi menjadi beberapa kelompok, kemudian diberikan Lembar Kerja Peserta Didik (LKPD) untuk dibahas bersama teman sekelompok mereka. Kegiatan tersebut mendorong peserta didik menemukan fakta sendiri, tidak hanya bergantung pada konsep materi yang terdapat pada buku saja, karena setiap pendapat yang diberikan oleh setiap peserta didik harus berbeda. Peserta didik dalam kelompok mengidentifikasi setiap hewan pada kelas Vertebrata, kemudian mengelompokkannya menjadi beberapa kelas, menggambarkan daur hidup serta peranan pada hewan-hewan tersebut. Dengan langkah yang sama pada pertemuan kedua baik kelas eksperimen maupun kelas kontrol membahas kelompok Reptil, Aves dan Mamalia dari kelas hewan Vertebrata.

Proses pembelajaran dengan metode brainstorming, peserta didik melengkapi data pengamatan dan menjawab pertanyaan yang terdapat pada lembar kerja peserta didik. Hal tersebut bertujuan untuk mendorong kemampuan berpikir kritis peserta didik dalam menemukan konsep pembelajaran hewanhewan Vertebrata secara mandiri. Proses penemuan konsep dilakukan selama proses pembelajaran setelah peserta didik mendapatkan informasi pada pra pembelajaran dan proses pembelajaran di sekolah. Metode brainstorming membebaskan peserta didik untuk dapat membentuk pengetahuannya sendiri. Seperti yang diungkapkan oleh Amin (2016) bahwa konsep metode pembelajaran brainstorming merupakan suatu upaya menjadikan proses belajar mengajar mengajar menarik dan bisa mendorong peserta didik aktif dalam belajar serta mengemukakan pendapat mereka (Amin, 2016). Proses pembelajaran dengan metode brainstorming memberikan kesempatan kepada peserta didik untuk mampu mandiri serta dapat mengarahkan diri sendiri, memiliki keterbukaan serta keutuhan diri dalam memilih alternative tindakan terbaik, dan dapat menyampaikan pendapat dalam memecahkan suatu masalah serta mampu menghargai pendapat orang lain (Damayanti, 2016). Pada proses pembelajaran konvensional, dimana peserta didik belajar dengan metode yang biasa mereka gunakan di dalam kelas, peserta didik juga belajar secara berkelompok yang terdiri dari 5-6 orang yang heterogen. Proses pembelajaran dengan metode ini melalui lima tahapan yaitu menyampaikan tujuan dan memotivasi peserta didik, menyajikan dan menyampaikan informasi, mengorganisasikan peserta didik dalam kelompok belajar, membimbing kelompok bekerja dan belajar, evaluasi dan memberikan penghargaan. Tahapan metode konvensional merupakan tahapan yang memang seharusnya dilakukan dalam suatu pembelajaran, berbeda dengan metode brainstorming yang menambahkan tahap-tahap pada kegiatan inti yang membuat siswa menemukan konsep secara mandiri, sehingga pada metode konvensional kurang memicu peserta didik berpikir kritis untuk memecahkan masalah.

Dalam proses pembelajaran konvensional, siswa juga diberikan lembar kerja yang sama untuk didiskusikan secara berkelompok. Hal tersebut dimaksudkan agar peserta didik pada kelas eksperimen dan kelas kontrol mendapatkan pengalaman belajar yang sama, baik dari segi materi yang dipelajari dan juga dari lembar kerja yang harus diselesaikan peserta didik melalui diskusi kelompok yang nantinya akan didiskusikan kembali bersama-sama setelah penyajian oleh kelompok siswa. Pada penelitian ini terdapat beberapa keterbatasan antara lain pada kelas eksperimen, peserta didik 
belum terbiasa menyampaikan pendapat mereka masing-masing sehingga guru harus benar-benar memberikan penegasan kembali bahwa setiap peserta didik harus menyampaikan pendapatnya sendiri serta dapat menarik kesimpulan selama proses pembelajaran. Selain itu, waktu yang dibutuhkan bagi peserta didik untuk dapat berpikir kritis juga seharusnya tidaklah singkat, melainkan butuh waktu yang banyak untuk dapat menciptakan pikiran kritis tiap peserta didik, akan tetapi yang digunakan dalam penelitian hanya 3 pertemuan pembelajaran saja.

\section{KESIMPULA}

\section{$\mathbf{N}$}

Berdasarkan hasil penelitian dapat Disimpulkan bahwa terdapat pengaruh metode brainstorming pada materi Vertebrata terhadap kemampuan berpikir kritis siswa SMA.

\section{UCAPAN TERIMA \\ KASIH}

Terima kasih kepada SMA Negeri 31 Jakarta, ibu Ratna Komala serta ibu Erna Heryanti, serta rekan-rekan sekalian yang telah membantu selama proses penelitian.

\section{DAFTAR}

\section{PUSTAKA}

Alawiyah, H. (2015). Analisis Kesulitan Belajar Siswa dalam Memahami Materi Invertebrata Di Kelas X Man 2 Pontianak. Skripsi. Pontianak: Program Studi Pendidikan Biologi, FKIP, Universitas Muhammadiyah Pontianak.

Amin, Diyah N. F. (2016). Penerapan Metode Curah Gagasan (Brainstorming) untuk Meningkatkan Kemampuan Mengemukakan Pendapat Siswa. Jurnal Pendidikan Sejarah Vol. 5
Ardian, Adan Riswan D. D. (2007).

Pengembangan Model Pembelajaran

Brainstorming untuk Meningkatkan

Kreatifitas Mahasiswa pada Mata

Kuliah Praktik Fabrikasi. Jurnal

Pendidikan Teknologi dan Kejuruan

17(1). Yogyakarta: Fakultas Teknik

Universitas Negeri

Yogyakarta

Ardiansyah, Hamdan. (2018). Pengaruh Metode Pembelajaran Brainstorming terhadap Kemampuan Berpikir Kritis berdasarkan Kemampuan Awal Peserta Didik. Jurnal Pendidikan Ekonomi Indonesia Vol.1 No.1

Arikunto, S. (2012). Prosedur Penelitian Suatu Pendekatan Praktek. Jakarta: Rineka Cipta

Damayanti, NP, Kt. Pudjawandan Md.

Suarjana. (2016). Pengaruh Metode Pembelajaran Brainstorming terhadap Kemamampuan Berpikir Kritis Siswa Mata Pelajaran Ipa Kelas V SD. EJournal PGSD 4(1). Singaraja: Universitas Pendidikan Ganesha.

Dimyati dan Mudjiono. (2006). Belajar dan Pembelajaran. Jakarta: Rineka Cipta

Ennis. (1996). Critical Thinking. New Jersey: Upper Sddle River

Fisher,A. (2007). Bepikir Kritis (Sebuah Pengantar) terjemahan. Jakarta: Erlangga

Malahayati. (2005). Berpikir dan Berhasil. Jakarta: Restu Agung

Mukrima, S S. (2014). 53 Metode Pembelajaran. Bandung: Pendidikan Manajemen Bisnis A Universitas Pendidikan Indonesia. 
Murti, B. (2016). Berpikir Kritis (Critical Thinking). Seri Kuliah Blok Budaya Ilmiah. Surakarta: Bagian Ilmu

Kesehatan Masyarakat, Fakultas

Moore Kedokteran, (20 Hniversitas Sebelas Thinking. McGraw.

Hill.

Nurafriani, Novi S. (2012). Pengaruh Metode Pembelajaran Brainstorming (Curah Gagasan) terhadap Kemampuan Berpikir Kritis Siswa pada Pembelajaran Matematika. Skripsi. Cirebon: Kementerian Agama Republik Indonesia Institut Agama Islam Negeri (IAIN)

Prihartiningsih, Siti Z dan Sentot K. (2016). Kemampuan Berpikir Kritis Siswa SMP Pada Materi Klasifikasi Makhluk Hidup. Jurnal Pros. Semnas Pendidikan IPA Pascasarjana UM (1). Malang: Universitas Negeri Malang.

Rahmawati, I, Arif H dan Sri R. (2016). Analisis Keterampilan Berpikir Kritis pada Siswa SMP Pada Materi Gaya Dan Penerapannya. Jurnal Pros. Semnas Pendidikan IPA Pascasarjana $U M$. Vol 1. Malang: Universitas Negeri Malang.

Rusman. (2010). Model-Model Pembelajaran. Jakarta: PT. Raja Grafindo Persada.

Sijabat, OP. (2013). Penerapan Metode Pembelajaran Brainstorming dalam Meningkatkan Aktivitas dan Hasil Belajar Akuntansi Siswa Kelas XI SMK Swasta Teladan Tanah Jawa Tahun Pelajaran 2013/2014. Laporan Penelitian Ilmiah. Fakultas Keguruan Dan Ilmu Pendidikan Universitas HKBP Nommensen: Pematangsiantar

Sumadji. (2015). Pengaruh Metode Pembelajaran terhadap Hasil Belajar Mahasiswa. Jurnal Inspirasi
Pendidikan 5(2). Malang: Universitas Kanjuruhan.

Susatyo, P dan Sugiharto. (2017). Struktur Hewan. Tanggerang Selatan: Universitas Terbuka.

Utami, D. (2015). Pengaruh Metode Brainstorming terhadap Kemampuan Berpikir Kritis pada Pembelajaran IPA. Jurnal PendidikanDasar 6 (2).

Wahyudi, M Zaid. 26 Agustus (2017). Industri Hoaks dan Jeratan Pikiran Kita. (diakses tanggal 29 Januari 2011

Zuqistya, N. (2014). Vertebrata. Jakarta Program Studi Pendidikan Biologi Jurusan Pendidikan Ilmu Pengetahuan Alam Fakultas Ilmu Tarbiyah dan Keguruan Universitas Islam Negeri Syarif Hidayatullah Jakart 